\title{
A Comparison of Some of the Themes of Irrationality, Illusion and Mystification Identified or Inferred by Karl Marx and Max Weber in Their Explanations of the Rise of Capitalism
}

\author{
J Forbes Farmer \\ Professor, Sociology Department, Franklin Pierce University, 40 University Drive, Rindge, \\ New Hampshire, USA. E-mail: Farmerjf@ Franklinpierce.edu.
}

Accepted: June 01, 2012 Published: July 19, 2012

Doi:10.5296/jsr.v3i2.2124

URL: http://dx.doi.org/10.5296/jsr.v3i2.2124

\begin{abstract}
This comparative study was undertaken in the belief that our understanding of the modern economic spirit, volatility of global markets and political activism can be furthered by revisiting Marx's and Weber's sociological, philosophical, economic and religious explanations of the rise of capitalism. The author identifies and reconsiders much of the scholarly literature on the argument that there are themes of illusion, mystification and irrationality in the classical theorists' explanations and that the themes are antagonists in much of the original writings.
\end{abstract}

\section{Introduction}

Capital is dead labor, which, vampire-like, lives only by sucking living labor, and lives the more, the more labor it sucks. (Marx, 1977: 342)

The impulse to acquisition, pursuit of gain, of money, of the greatest possible amount of money, has in itself nothing to do with capitalism. (Weber, 1958:17)

The aim of this work is to reconsider some Karl Marx (1818-1883) - Max Weber (1864-1920) comparative scholarship. The boldness, energy, life and enthusiasm running through the original writings of these two German framers of modern sociology should be kept fresh during this current time of economic and market volatility, and remembered as the ideas that left quite an indelible impression upon their contemporaries and those who have followed. 


\section{Macrothink}

Etzrodt (2008:63) asserted that, "Modern economic theories are largely consistent with Weber's economic spirit." Dowd (2002:247) declared that, "The Marxian analytical framework remains essential for the understanding of contemporary capitalism." One particularly exciting theme is the omnipresent illusion, irrationality and mystification which serve as the ferret-like antagonists in these otherwise rational social theories that explain the rise of capitalism. The approach used here will be to first identify some ways in which Marx and Weber's methods are involved with these issues and then shift to a more specific analysis of the force and control function of illusion and irrationality, its presence in charisma, its possible interchangeability with mystification, its presence in commodity fetishism and its role in the future.

The influence of these antagonists, although constant, is particularly difficult to identify because, as Weber (1958:194) pointed out in a footnote in The Protestant Ethic and the Spirit of Capitalism, "a thing is never irrational in itself, but only from a particular rational point of view." An example of this is that, for Marx, the workers wage is both a rational minimization of the costs of production and at the same time it is, to use the Weberian term, "substantially irrational." Sometimes there are competing rationalities that give the illusion of irrationality and often what may have been rational in a past culture appear irrational years later. Weber and Marx, in offering new explanations for the rise of capitalism and the spirit and future of mankind, were influenced by these illusions and were interested in shedding light on them. Naturally, as one goes about the task of demystifying illusions, one can be accused of being irrational in the process. Nevertheless, some interesting documentation has been uncovered despite the fact that Weber doesn't really have a fully developed conception of irrationality (Mehta 2001:207). For Marx, of course, the issue was quite central (Cauchi, 2011; Dowd, 2002).

\subsection{Elucidating the Irrational}

It was Marx who said in Capital (1974), "I presuppose, of course, a reader who is willing to learn something new and therefore to think for himself" (Tucker, 1972:192). One wonders how many readers had their illusions shattered or what kind of an impact Marx made with his reference in The German Ideology to the hanging, by Henry VIII of England, of 72,000 vagabonds (Tucker, 1972:145). It is known, of course, that in Pius IX's first encyclical, Qui pluribus in 1846, it was said:

You well know the monstrous errors and artifices which the children of this century make use of in order to wage relentless war against the Catholic faith... Such is the object of the execrable doctrine called communism: it is wholly contrary to natural law itself... (Fremantle, 1956:130)

Pius IX's encyclical and Henry VIII's hangings represent the difficulty one has in separating the rational from the irrational, but the examples also serve as evidence of "the more 
powerful side of the conflict tradition of which Engels and Marx were progenitors" (Collins, 1984:257). In Capital (1974), Marx stated his objective as being "to lay bare the economic law of motion of modern society" (Sweezy, 1981:12). Major illusions were uncovered as Marx went about this task.

By dividing surplus value into two parts, Marx was able to lay bare the anatomy of the class struggles that have been at the heart of the process of capitalist development from the beginning, and the very existence of which is ignored or denied by neoclassical economics. (Sweezy, 1981:30)

This broken illusion revealed the exploitive system of surplus extraction that could be argued to lead to a maldistribution of wealth and power, but doing so in an invisible form (Cauchi, 2011; Dowd, 2002). Whether one sees surplus value extraction as rational or irrational depends upon your point of view. There are certainly those critics on the political left (Ruccio, 2011:225; Wright, 2010) who lament the irrationality of capitalist class-exploitation, and who argue for a more socialistic world.

Collins (1980:941) considered Weber "a more thoroughgoing conflict theorist" than Marx. For Weber "the conditions of rationalized organization, in political and economic spheres alike, depend upon a continuous open struggle" (Collins, 1980:941). Weber recognized the necessary reciprocity between the rational and irrational (Whimster, 2005:305), but thought it could best be explained by looking at individual social action and interpretative understanding (verstehen) of social behavior. According to some commentators (Bendix, 1962:489; Mehta, 2001:203), Weber was indebted to German legal theory and German cultural history for this focus.

Legal theorists had concerned themselves with the logical problem of attributing an action such as a criminal act to an individual to determine his culpability, and Weber adapted this approach to his own needs when he developed his theory in terms of the meaning that men associate with their action in society. (Bendix, 1962:489)

Some theorists (Forte, 2008:435) saw Weber's sharing with others "whatever mystified conception they have of themselves," (verstehen), being incompatible with Marx's interest in presenting human action in history as it really was. The irrationalism of tradition was significantly involved in the development of Marx's ideas (Cauchi, 2011; Grossman, 2006). Giddens (1970:291), for example, wrote, "Indeed, it might be said the Marx's awareness of the very backwardness of Germany in its social and economic structure was at root of his original conception of the role of the proletariat in history." For Marx, of course, the capitalist and the proletariat are both operating rationally; it's not that one is rational and the other irrational. The attention Marx gave to the illusiveness of the irrational might have inspired his insistence upon use of the scientific method. Howard (1977) saw Marx's task as being that of "extracting the rational kernel, the reality beneath the mystification, the essence is that here 
rational equals real equals essential" (Howard, 1977:282). Keat and Urry (1982:192) wrote "For Marx, two elements of an adequate theory are: first, to represent the beliefs which are held by the members of society; second, to know how some of these are false, and why they develop and are sustained."

It is easy to see that Weber had similar interests in elucidating the irrational. In Protestant Ethic and the Spirit of Capitalism, he said "Puritanism included a world of contradictions" (Weber, 1958:169). Grossman (2006:211) believed it was the "generally irrational presuppositions... of predestined salvation through faith" that facilitated the emergence of capitalism. Ascher (2012:106) argued, "The Puritan wanted to work in a calling, Weber tells us, whereas we are forced to. But think of it: was not the Puritan also compelled, if only by an irrational fear of a wrathful God?" Birnbaum (1953:125) claimed that a major theme in Weber's work was "the function of ideology as an independent variable in social development." Bendix showed how Weber has adopted Hegel's idea that "society and government stand in a reciprocal relation to each other" (Bendix, 1962:494). Much more attention will be given to Weber's interest in these areas later. For now it will suffice to make the opening argument that mystification, illusion and irrationality played important antagonistical roles for both Weber and Marx.

Keat and Urry (1982) pointed out that Marx defended the position that Praxis was more than something uncontrollable. They showed that Marx, in The German Ideology (1976), "considers as ideological distortion the seeing of the social relations of production specific to the capitalist mode, as natural and eternal" (Keat and Urry, 1982:177). Marx, of course, began by applying Feuerbach's idea and turns Hegel's political philosophy upside down. "For Hegel society is a manifestation of the state. This, said Marx, is a mystification" (Tucker, 1961:104), the people create the political system not the other way around. In the afterword of the second German edition of Capital, Marx wrote, "The mystifying side of Hegelian dialectic I criticized nearly thirty years ago, at a time when it was still the fashion" (Tucker, 1972:197). The anti-Marxist Tucker pointed out that this reference was to an "unpublished manuscript of 1844 on the Hegelian dialectic and philosophy as a whole, whose very existence still remained unknown to the world" (Tucker, 1961:129). Sweezy wrote that The German Ideology (1976) makes it clear that materialism, for Marx and Engels, was the "obverse and alternative to idealism" (Sweezy, 1981:16).

In its mystified form, dialectic became the fashion in Germany, because it seemed to transfigure and to glorify the existing state of things. In its rational form it is a scandal and abomination to bourgeoisdom... Capital (Afterword) (Tucker, 1972:198)

In demystifying the Hegelian dialectic, Marx set forth his historical materialism which explained prehistory as a sequence of necessary but progressive stages. In so doing, Marx left individual motivation relatively unexplained and implicit. Weber, on the other hand, was explicit in his assertion that religion helped people find order and meaning in their lives 
(Mehta, 2001:221). When Weber traced religion's influence in The Protestant Ethic and the Spirit of Capitalism (1958) he "challenged the Marxist thesis that man's consciousness is determined by his social class" (Bendix, 1962:49). While Marx had an optimistic appraisal of human destiny, similar to Comte's positivism, Weber, as will be shown later, was pessimistic. Marx helped rescue men "from the fears and illusions of theology and metaphysics by a scientific habit of thought" (Masterson, 1971:105). For Marx, religion was "an illusion, an opiate to be abandoned" (Forte, 2008:429).

Marx accepts without reservation that the critique of religion must be total and radical to the point of affirming man as the only absolute. While Weber put together a kind of epistemological relativism "where everything, including science, becomes a value relative to some other framework." (Masterson, 1971:83)

\subsection{Panoramas of Contradictions}

In answering some anti-Marxists, Collins (1984:257) countered by saying that "if the Marxian system failed empirically, it was because of the weakness of its economics, not the solider sociological components - the Engelsian side, if you will." Anti-Marxists like Tucker saw additional failure in Marx's method by pointing to an apparent paradox in Marx's disclaimer of intent to moralize with what they believed were "intensely moralistic tones" (Tucker, 1961:15). Tucker believed Marx described a world which was wrong and evil, but Tucker admitted to having difficulty proving this analytically. Sweezy (1942:20) argued that many of Marx's critics consciously or unconsciously reject Marx's working assumptions. There are other scholars (see Forte, 2008:445) who support Marx's contributions; particularly their influence on Weber's conditions for the emergence of capitalism. It was Bendix (1962:481) who wrote "Weber transformed the great insight of Marx by showing that material interests are linked to man's inveterate quest for meaning and idealization, and that neither can be understood apart from the other." Mehta (2001:220) showed how Weber related religion to human suffering; clearly also a favorite focus for Marx.

The illusions, irrationality, mystifications and reifications identified, addressed and inferred by Marx and Weber are particularly vivid as agents of force and control. Some are present as ideologies. In Capital I (1974) Marx wrote "capital is dead labor, that, vampire-like, only lives by sucking living labor, and lives the more, the more labor it sucks" (Tucker, 1972:251). And in his discussion of the lack of full-scale capitalist development in Rome, Marx cited ideological pressure against the accumulation of wealth for its own sake as one of the significant inhibiting factors (Giddens, 1970:301). In another example of the influence of the irrational Weber (1958:167) wrote in The Protestant Ethic and the spirit of Capitalism (1958):

The feudal and monarchial forces protected the pleasure seekers against the rising middle-class morality and the anti-authoritarian ascetic conventicles, 
just as today capitalistic society tends to protect those willing to work against the class morality of the proletariat and the anti-authoritarian trade union.

It has already been shown in Pius IX's Qui pluribus that Marxism was a threat to the established order. This was the first encyclical to have pointed to the danger of communism and revolutionary thought, but it was not the last to support (the irrationality of) tradition. Leo XIII's Rerum Novarum was a forceful reaction to Marx and exemplifies both the reoccurring conflict between reason and tradition and the usage of illusion as ideology. After calling Marx and his followers "crafty agitators intent on making use of differences of opinion to pervert men's judgments and to stir up the people to revolt" (Fremantle, 1956:167), Leo XIII continued in his 1891 encyclical:

Hence it is clear that the main tenet of socialism, community of goods, must be utterly rejected, since it only injures those who it would seem meant to benefit, is directly contrary to the natural rights of mankind, and would introduce confusion and disorder into the commonweal. (Fremantle 1956:172)

In addition to the antagonism of the Catholic church, Marx had to contend with the flaws in the reasoning of Ferdinand Lasalle. In the Critique of the Gotha Program ([1875] 1970), Marx wrote, "So, in the future, the German workers' party has got to believe in Lasalle's iron law of wages!" (Tucker, 1972:391). Another place where Marx called attention to the ironies and irrationalities of the times was in the Inaugural Address of the International Working Men's Association [1864] when he cited the Blue Book of 1863 as having proven "that the worst of the convicted criminals, the penal serfs of England and Scotland, toiled much less and fared far better than the agricultural labourers of England and Scotland" (Tucker, 1972:375).

If more convincing is necessary to prove the point that these panoramas of contradictions are flirtations with the irrational then one can turn to The German Ideology (1976) and find Marx commenting on the division of labor and writing "as long as a cleavage exists between the particular and the common interest,... man's own deed becomes an alien power opposed to him, which enslaves him instead of being controlled by him" (Tucker, 1972:124). And one final argument can be made to support the same point about the irrational. In the Manifesto of the Communist Party (1978) where Marx summarized his theory of history he showed how the bourgeoisie furnished the proletariat with weapons for fighting the bourgeoisie (Tucker, 1972:343).

\subsection{Elements of Force and Control}

The rational element emerges in contrast to the illusions. In the Selected Works (1970), Marx and Engels present the proletarian as "history's might act of retributive justice against a society so criminal in character that it deserves capital punishment" (Tucker, 1961:15). But again, the echo of the Catholic Church rang out. This time, forty years after Leo XIII, Pious 
XI sent out Quadragesimo Anno.

The workers, on the other hand, crushed by their hard lot, were barely enduring it and were refusing longer to bend their necks beneath so galling a yoke; and some of them, carried away by the heat of evil counsel, were seeking the overturn of everything... (Fremantle, 1956:229)

The elements of force and control have been seen to be related to reason and irrationality in antagonistic ways; each bringing forth stronger claims by the other in the period of capitalist development which Marx and Weber agreed emphasized rationality. Even in Marx's account of the breakup of the Feudal system and the rise of the merchant class in England, Marx treated rationality as a product of social development. His explanation "rested heavily on elements of compulsion and external pressure" (Birnbaum, 1953:135). But the mystical explanation lurks in contrast. As Weber (1958:160) explained in The Protestant Ethic and the Spirit of Capitalism, the differentiation of men into classes became for Luther, "a direct result of the divine will."

The issue of irrationality becomes more pronounced in Weber's work particularly in regards to religion (Ascher, 2012; Mehta, 2001; Whimster, 2005), charisma and ideal types (Nafissi, 2000) to which attention is soon turned more specifically, but the comparison with Marx on this central theme will not be lost as it will be important to return to the mystification of Hegel and the illusions of capitalism including alienation and commodities at a later time. It is important now, however to reemphasize what Habermas called "the peculiar tension between rationality and irrationality that haunts the positivist understanding of the relation of theory to practice in general" (McCarthy, 1978:6). Turner (1983:514) wrote of Weber that he was careful to stress the equal validity and necessity of both rational and irrational ideal types of sociological explanation.

Many examples have been used to this point to clarify the broad sense of "irrationality." Keat and Urry (1982:156) provided more input when they wrote "a person who persistently fails, in the absence of preventing conditions, to act in the manner appropriate to his or her beliefs and desires may come to be regarded as fundamentally irrational.” Keat and Urry (1982:215) warned that something might be called irrational when in fact it has been misunderstood, but an attempt was made earlier to guard against this danger by recalling Weber's notion that irrationality exists only from a particular ration point of view. Without getting into the difference between what is irrational and non-irrational, is might be useful to mention that Keat and Urry (1982:209) said that "beliefs that are held on appeal to authority are non-ration." As Habermas once said:

All practical questions that cannot be posed and solved technically, that go beyond considerations of economy and efficiency of means, feasibility of ends, and the like, cannot be rationally resolved. They must be left to decisions that are, in the final analysis, subjective and irrational. (McCarthy 1978:7) 
One final thought on this question comes in contrast to Aquinas' position (Pegis, 1948:190) and that is Habermas on Hegel's experience of reflection when he said "the conditions of rationality change irrationally, according to time and place, epoch and culture" (McCarthy, 1978:182).

Historical reference to irrationality was made by Weber (1958:20) in The Protestant Ethic and the Spirit of Capitalism when he spoke of money-lenders as irrational and speculative characters "directed to acquisition by force." Bendix (1962:57) wrote of the rising middle class in the age of Reformation as having "deviated significantly from the simple acquisitiveness, religious indifference and more or less outright hedonism" of social economic groups. Birnbaum spoke of medieval Catholicism as offering escape from rationalism (Birnbaum, 1953:138), and wrote, "Wars exhausted the feudal ruling class while it's irrational and spendthrift way of life (itself a factor in causing these wars) emphasized consumption and not production" (Birnbaum, 1953:135). He referred also to the "magical character of medieval European culture" (Birnbaum, 1953:127).

A constant reminder of the opposite side of the irrational platform is Leo XII in Rerum Novarum "as regards the State, the interests of all, whether high or low, are equal. It would be irrational to neglect one portion of the citizens and favor another..." (Fremantle, 1956:181). But Weber in The Protestant Ethic and the Spirit of Capitalism, said of the medieval Catholic layman "his good works did not necessarily form a connected, or at least not a rationalized system of life" (Weber, 1958:116). And back to Leo XII again in Rerum Novarum:

The great mistake made in regard to the matter now under consideration is to take up with the notion that class is naturally hostile to class and that the wealthy and the working-man are intended by nature to live in mutual conflict. So irrational and so false is this view, that the direct contrary is the truth. (Fremantle 1956:174)

The Protestant church gave work "a rational quality through an irrational process" (Cuzzort and King, 1980:85). The religious writings of Luther and Calvin were given mystical qualities and Weber "specifically dissociated himself from the mystical advocacy of the German state" (Giddens, 1970:294). Weber, of course, in The Protestant Ethic and the Spirit of Capitalism wrote of the spirit of capitalism "the acquisition of more and more money, combined with the strict avoidance of all spontaneous enjoyment...appears as quite transcendental and wholly irrational" (Weber, 1958:53) from the standpoint of eudemonistic self interest. Ascher (2012) and Etzrodt (2008) discussed how this economic spirit was irrational. The traditional motivation for economic activity was consumption. But why should people produce if they were not allowed to consume?

As was previously mentioned, Weber paid a great deal of attention to the irrational and the mystical and in further support of his belief that both the rational and irrational are important 
in sociological study he asserted "mysticism may indirectly even further the interests of rational conduct" (Weber, 1958:113). In The Religion of China ([1915] 1964), Weber compared Confucian rationality with rational Puritanism and says they are very different in their irrationalities of reality (Giddens, 1971:177). He also said of Christian asceticism:

It has become emancipated from plan less otherworldliness and irrational self-torture. It had developed a systematic method of irrational self-torture. It had develop a systematic method of rational conduct with the purpose of overcoming the status nature, to free man from the power of irrational impulses and his dependence on the world and on nature. (Weber, 1958:118)

This sounds somewhat like the action suggested by Feuerbach's position; that to "eliminate human self-alienation all that needs to be done is for religion to be de-mystified, and placed on a rational level" (Giddens, 1971:299). According to Giddens, Marx saw a defect in this view. "Weber, too, tried to protect man's reason by first understanding man's foundations and consequences of rational action" (Bendix, 1962:471). Giddens pointed out that herein lies a major difference between Marx and Weber. Weber believed that human history was not rational and the concept of charisma is proof of this. Marx, of course, thought human prehistory to be rational.

The attribution of a discoverable rationality to history is an essential element of a discoverable rationality to history is an essential element in the whole of Marx's thought... but charisma is specially irrational; thus the revolutionary dynamic in history, which for Weber is constituted by the periodic emergence of charismatic movements, cannot be connected to any overall rational pattern in the historical development of man. (Giddens, 1970:161)

\subsection{Charisma}

Charisma, for Weber, was an irrational phenomenon which was a "driving, creative force which surges through the established rules, whether traditional or legal, which govern an existing order" (Giddens, 1970:161). Keat and Urry (1982:220) wrote that for Weber, a society that is rational "can thus be criticized for the irrationality of the ends pursued in it."

The rise of capitalism was also partly dependent upon a separation from the irrational (Whimster, 2005:307). Weber believed that when looked at from the capitalist standpoint, the traditional practice of limiting the number of workers in the craft guilds was irrational because maximum productivity of labor was not yielded. There was an "irrational, almost limitless waste of labor which is characteristic of petit-bourgeois morality" (Grossman, 2006:205). Birnbaum (1953:129) wrote that Weber argued that the maximization of technical efficiency was "fundamentally incompatible with the magical or sacramental view of the world. Marx, too, recognized the connection between the emergence of capitalism and the banishment of magic from the West." And Giddens wrote of The Protestant Ethic and the 
Spirit of Capitalism that "the distinctive feature of the work is that it seeks to demonstrate that the rationalization of economic life characteristic of modern capitalism connects with irrational value-commitments" (Giddens, 1970:131). Giddens, of course, must be basing his argument on such passages in Weber (1958:53) as:

In fact, the sum mum bonum of this ethic, the earning of more and more money, combined with the strict avoidance of all spontaneous enjoyment of life, is above all completely devoid of any eudemonistic, not to say hedonistic, admixture. It is thought of so purely as an end in itself, that from the point of view of the happiness of, or utility to, the single individual, it appears entirely transcendental and absolutely irrational.

In referring to what Weber called this reversal of a natural relationship, Bendix (1962:140) wrote "there is then a strange relation between what men intended by their acts and what actually comes of them - the paradox of unintended consequences." About the irrationality of this sort of life, Weber (1958:70) said, "A man exists for the sake of his business, instead of the reverse," and he saw capitalism as a rational tempering of the irrational impulses. "A man does not by nature wish to earn more and more money, but simply to live as he is accustomed to live and earn as much as is necessary for that purpose" (Weber, 1958:60). For Marcuse, the elimination of this irrational predicament requires "the transformation of society into one where the means of production are controlled by the community... and this must start with an evaluation of existing reality as fundamentally irrational" (Keat and Urry, 1982:219).

Up to this point, the theme of irrationality, illusions and mystifications has been concerned with the conflict between Marx and the Catholic church, Weber's attention to charisma and the calling, the pursuit of wealth in capitalism, the importance of rationality in Marx and Weber's methods, the irrationality of religion and traditionalism and the important interplay between the rational and irrational ideologies. It must now be shown more specifically how mystifications are part of the illusive antagonisms.

\subsection{Mystifications}

Keat and Urry (1982:213) cited how Evans - Pritchard defined "mystical notions" as "patterns of thought that attribute to phenomena suprasensible qualities which, or part of which, are not derived from observation or cannot be logically inferred from it, and which they do not possess." The anti-Marxist Tucker believed that a characteristic of true mythic thinking is that "the thinker is not aware of it as mythical" (Tucker, 1961:224). It should be recalled that Hegel had seen history as a process of movement towards the Absolute and Geist was the driving force that took the form of Nation States. Swedberg (2002:249 and Ascher (2012:102) point out that Geist or Beruf was also the driving force for Weber. For Hegel, man was the world in self-estrangement. Feuerbach construed this as a mystified revelation of the universally self-estranged condition of man and said that God is man in self-estrangement. In Selected Correspondence ([1858] 1942) is included a letter by Marx to Engels where he said that he wants to "make accessible to the ordinary human intelligence, in 
two or three printer sheets, what is rational in the method of Hegel but at the same time enveloped in mysticism" (Tucker, 1961:170). Marx held that man was alienated from himself as a result of striving for the Absolute. Critics of Marx, like Tuck, argued that Marx's image of society and alienation was itself a myth. Tucker (1961) in Philosophy and Myth in Karl Marx repeated this theme many times. Keat and Urry (1982:179) claimed that Marx "clearly emphasizes that what people experience within capitalism and how they conceptualize it, is not illusory."

Capitalist society, for Marx, is not observed a-theoretically yet incorrectly; it is rather that the mechanisms of that society produce false theories embedded within the descriptions, perceptions, and experiences of people that live in that society. (Keat and Urry, 1982:179)

Tucker (1961) believed that Marx was terribly caught up in his own myth and was blind to everything else. He claimed Marx "heard the rumblings of the world-historical volcano in every manifestation of unrest on the surface of European society. This was an outgrowth of the fact that his (Marx) central vision of the world was mythic in character" (Tucker, 1961:226). Keat and Urry argued that the most crucial is the truth or falsity of social theories and that this question can only be answered by looking at the "relations between the knower and the known, the 'subject' and the 'object' of knowledge" (Keat and Urry, 1982:143). Frankfort believed that mythic presentations are "products of imagination but they are not mere fantasy... true myth presents its images and its imaginary actors, not with the playfulness of fantasy, but with a compelling authority" (Frankfort, 1949:15). What Marx actually saw, said Tucker (1961:220), "is an inner reality, a subjective world, but he does not see it as subjective... he has entered completely into the myth." Tucker believed that the classic vehicle of this mystification is Capital.

In response to this question of reification in the capitalist mode of production, Keat and Urry (1982:193) took the negative position. Slaughter, on the other hand said "capitalism appears to allow freedom, to promote the flourishing of individuality, this is an illusion" (Richmond-Wilner, 1982:640). Giddens provided more spark for this question when he wrote of what Weber had called "the historical impulse towards the elimination of magic from the daily conduct of life' that process of the 'disenchantment' of the world which reaches it culmination in rational capitalism" (Giddens, 1970:171). Whimster (2005:315) referred to this as the "profound unease" with the constraints capitalism imposed.

The reappearing antagonism in this debate over the irrational and mystification is nowhere more vividly marked than in the discussion of capitalist commodities (Forte, 2008:439). It is found in Keat and Urry (1982:180) "for Lukacs the essential feature of capitalism is commodity fetishism; and the main product of such fetishism is reification." In Capital I (1974) Marx wrote:

A commodity is therefore a mysterious thing, simply because in it the social 


\section{MInstitute Macrothink}

character of men's labor appears to them as an objective character stamped upon the product of that labor; because the relation of the producers to the sum total of their own labor is presented to them as a social relation, existing not between themselves, but between the products of labor. This is the reason why the products of labor become commodities, social things whose qualities are at the same time perceptible and imperceptible by the senses. (Tucker 1961:216)

\section{And in Capital III}

We have the complete mystification of the capitalist mode of production, the transformation of social conditions into things... It is an enchanted, perverted, topsy-turvy world in which Monsieur le Capital and Madame la Terre carry on their goblin tricks as social characters at the same time as mere things. (Sweezy, 1942:38)

In the Critique of the Gotha Program (1970), Marx said "the bourgeois have very good grounds for falsely ascribing supernatural creative power to labor..." (Tucker, 1961:383). Sweezy (1942), on the reification of social relations, believed that this is the core of Marx's doctrine of fetishism and he pointed out that Marx in A Contribution to the Critique of Political Economy ([1859] 1999) said that the reification of social relations was impossible in early periods of history and even in the early stages of commodity production itself "this mystification is as yet very simple" (Sweezy, 1942:35).

On the impact of this irrationalization, Keat and Urry (1982:185) believed that all social institutions are similarly reified by "mystifying their true nature as human ojectivations." This happens according to Keat and Urry, at both the theoretical and individual levels. Masterson (1971:86) agreed.

The various systematized modalities of cultural life such as law, politics, philosophy and religion are merely ideological mystifications which accompany this basic exploitation. The mysterious feature of the history of man is that he has been enslaved by an ideological illusion of his own making.

The importance of freeing man from these irrationalities is a major theme in both Marx and Weber. In the Contribution to the Critique of Hegel's Philosophy of Right ([1844] 1970) Marx says "the abolition of religion as the illusory happiness of men, is a demand for their real happiness" (Tucker, 1961:12). Tucker believed that the "religious essence of Marxism is superficially obscured by Marx rejection of the traditional religions. This took the form of a repudiate of 'religion' as such and an espousal of 'atheism'” (Tucker, 1961:22). A return to Marx, this time in The German Ideology (1976), will reveal:

The whole trick of proving the hegemony of the spirit in history is to... No. 2 Prove a mystical connection among the successive ruling ideas. No. 3... to 
remove the mystical appearance of this self determining concept. (Tucker, 1961:139)

Keat and Urry (1982) argued that there are two forms of ideology which both involve distortion, but that the specific kinds of distortion are different. One type, they say, is the Marxist type of distortion that takes the form of reification resulting in a defect of ideological beliefs. The other form of distortion is the intrusion of values into the scientific method (Keat and Urry, 1982:143). There is, said Habermas, "a core of irrationality in the orientation to values, goals, and needs" (McCarthy, 1978:9).

The mystification, reification and irrationalities involved in the repudiation of religion, the development of capitalism and the estrangement of the proletariat are all interwoven with the rationalities of the times as has been partly shown already, but there are several major points that should not be lost. First of all, in Weber's nineteen page introduction to The Protestant Ethic and the Spirit of Capitalism there are sixteen pages with direct mention of rationalism. The word "rational," or some form of it, appears fifty-five times. In the text Weber (1958:117) equated the rationalization of the world with the "elimination of magic as a means to salvation." As Keat and Urry (1982:220) pointed out, "for Weber, judgments of rationality are limited to an assessment of the relations between means and ends, and of the internal consistency of a given set of ends. But there is no possibility of evaluating the ends themselves as rational or irrational."

Weber continuously equated irrationality with traditionalism and the hand-to-mouth existence of the peasant and contrasted this with the "rigorous calculation" of capitalism. He also contrasted the irrationality of tradition to both his types of rational action, Zweckrational and Wertrational. Turner (1983:511) pointed out that Weber manages to refrain from giving "objective correctness any special metaphysical status in relation to explanation." Giddens (1970) and Howard (1977) were remindful that Marx, as was Weber, was very conscious of the rational. "The rationalizing character of capitalism is manifest most directly, for Marx, in the utter dominance of money in human social relationships, and of the pursuit of money as an end in itself" (Giddens, 1970:302). And finally, on a much larger scale, Howard (1977) recalled that for Marx the assumption is that "history and its milieu are ultimately progressing towards a goal which is already essentially prefigured in the present. A telos is presupposed" (Howard, 1977:282).

\section{Conclusion}

It is in this direction that the final concluding discussion must move. How did Marx and Weber see the future? Although Marx received discouragement in the failure of some revolutionary attempts, he was optimistic that mankind would end its prehistory and make history in the communist, classless state. Whereas at one point it seemed irrational that the human species alienated itself from itself, on the other hand there was the rational anthropogenesis. Weber was pessimistic about the individual's plight (Whimster, 2005:315). 
He was very impressed by a lot of features of capitalism that Marx knew about and mentioned, but never subjected to detailed analysis. One of these is what Weber called the "rationalization of life." This began, of course, with the rationalization of productive life and his analysis of the nature of the factory. Collins (1980:941) pointed out that:

The main disagreements between Marx and Weber have less to do with the origins of capitalism than with its future. Weber thought that capitalism could endure indefinitely as an economic system, although political factors could bring it down... the disappearance of religious legitimation in mature capitalism could open the way for a political movement for socialism.

The individual, in Weber's analysis, was doomed to live in the "Iron Cage" where material goods and the rationalized bureaucratization would have an inexorable power over mankind. Whimster (2005:315) believed that Weber saw people having "professional vocation but no spirit" and pursuing self-interest with no feeling. For Bendix (1962:471), Weber's research left no doubt that "in the modern world reason and freedom are in jeopardy." The future would see "the drama of a hero in irons." As Giddens (1970:298) wrote, it was this "epistemological position that Weber recognized which separated him most decisively from Marx." Marx's work involved an ethic of ultimate ends; Weber's did not.

Marx tended to reduce the creative ambiguity of choice in history, conceptualizing it in a linear-progressive fashion and subjecting it to a philosophical rationalism. The past was seen as absorbed into the present, itself pregnant with a future which would, ultimately, eliminate irrationality and scarcity - and finally, (pre) History itself. (Howard, 1977:286)

It should be restated in this conclusion what must now be clear; that illusion, mystification, irrationality and reification are phantom antagonists in almost every aspect of Marx's and Weber's theoretical explanations of the rise of capitalism. An attempt has been made here to ferret out some documentation supporting this argument. It has been seen how interconnected rationality and irrationality are in the theorizing about the process. It is very hard to separate the history of capitalism as a succession of progressive systematic steps from the history with an individualistic element. This is one very special reason why Marx and Weber should be companion readers. While looking at the antagonisms between rationality and irrationality an attempt was made to look at them separately and together in the methods of Marx and Weber and in their major themes of religion, commodities, alienation, capitalism, traditionalism and their view of the future.

\section{References}

Ascher, Ivan. 2012. "Max Weber and the 'Spirit' of The Protestant Ethic." Journal of Classical Sociology 10: 99-105. 


\section{Macrothink}

Journal of Sociological Research

ISSN 1948-5468

2012, Vol. 3, No.2

Bendix, Richard. 1962. Max Weber: An Intellectual Portrait. New York, NY: Anchor Books. Birnbaum, N. 1953. "Conflicting Interpretations of the Rise of Capitalism: Marx and Weber." British Journal of Sociology 4: 125-141.

Burris, Val. 1982. "Reading Marx.” Contemporary Sociology 11(6): 642-644.

Cassirer, Ernst. 1946. Language and Myth. (Trans. By Susanne Langer). New York, NY: Harper and Brothers.

Cauchi, Mark. 2011. "Creation and the Critique of Capitalism in Marx, Nancy and Zizek." Political Theology 12(4): 531-552.

Chadwick, Owen. 1975. The Secularization of the European Mind in the Nineteenth Century. Cambridge, England: Cambridge University Press.

Collins, Randall. 1984. "Alexander and the Transcendence of Sociology." Contemporary Sociology 13(3): 255-257.

Collins, Randall. 1980. Last Theory of Capitalism: A Systemization.” American Sociological Review 45(6): 925-941.

Crane, Jeffery. 1982. "Habermas and Hegel: Possible Contributions to a Unified Social Theory." Contemporary Sociology 11(6): 636-638.

Cuzzort, Ray P. and Edith King. 1980. 20 ${ }^{\text {th }}$ Century Social Thought. $3^{\text {rd }}$ Edition. New York, NY: Holt, Rinehart and Winston.

Dowd, Doug. 2002. "Depths below Depths: the Intensification, Multiplication, and Spread of Capitalism's Destructive Force from Marx's Time to Ours. Review of Radical Political Economics 34: 247-266.

Etzrodt, Christian. 2008. "Weber's Protestant-Ethic Thesis, the Critics, and Adam Smith." Max Weber Studies 8(1): 49-78.

Forte, Juan M. 2008. "Religion and Capitalism: Weber, Marx and the Materialist Controversy." Philosophy and Social Criticism 34(4): 427-448.

Frankfort, Henri. 1949. Before Philosophy. New York, NY: Penguin Books.

Fremantle, Anne. (Ed.) 1956. The Papal Encyclicals in Their Historical Context. New York, NY: The New American Library of World Literature, Inc.

Giddens, Anthony. 1971. Capitalism and Modern Social Theory. Cambridge, England. 
Cambridge University Press.

Giddens, Anthony. 1970. "Marx, Weber and the Development of Capitalism." Sociology 4(3): 289-310.

Grossman, Henryk. 2006. The Beginnings of Capitalism and the New Mass Morality." Journal of Classical Sociology 6(2): 201-213.

Hilton, Rodney. 1976. The Transition from Feudalism to Capitalism. London, England: New Left Books.

Hoselitz, Bert F. 1960. Sociological Aspects of Economic Growth. New York, NY: The Free Press.

Howard, Dick. 1977. The Marxian Legacy. New York, NY: Unizen Books.

Kasler, Dirk. 1984. “Originality by Misrepresentation.” Contemporary Sociology 13(3): 258-260.

Keat, Russell and John Urry. 1982. Social Theory as Science, 2nd Edition. London, England: Routledge and Kegan Paul, Ltd.

Laski, Harold J. 1967. Harold J. Laski on the Communist Manifesato. New York, NY: Random House, Inc.

Marx, Karl. [1859] 1999. A Contribution to the Critique of Political Economy. Moscow: Progress Publishers. On-line version: Marxists.org.

Marx, Karl. 1977. Capital. Vol. 1. New York, NY. Random House.

Marx, Karl. [1844] 1970. Contribution to the Critique of Hegel's Philosophy of Right. (Trans. by Annette Jolin). Cambridge, England; Cambridge University Press.

Marx, Karl. [1875] 1970. Critique of the Gotha Program. In Marx/Engels Selected Works, Vol.3:13-30. Moscow, Progress Publishing.

Marx, Karl. [1864] Inaugural Address of the International Working Men's Association. In Inaugural Address and Provisional Rules of the International Working Men's Association. Available online at Marxists.org.

Marx, Karl. 1978. Manifesto of the Communist Party. In The Marx-Engels Reader $\left(2^{\text {nd }}\right.$ Edition). (Ed. By R.C. Tucker. New York, NY: W.W. Norton. 


\section{Macrothink}

Journal of Sociological Research

ISSN 1948-5468

2012, Vol. 3, No.2

Marx, Karl. [1858] 1942. Selected Correspondence, 1846-1895. New York, NY; International Publishers.

Marx, Karl. 1976. The German Ideology. (Trans. by W. Lough). In Karl Marx, Friedrich Engels, Collected Works, Vol. 5: Marx and Engels 1845-47. New York: International Publishers.

Marx, Karl. 1968. Theories of Surplus Value. New York, NY: Augustus M. Kelley Publishers.

Masterson, Patrick. 1971. Atheism and Alienation. Notre Dame, Indiana: University of Notre Dame Press.

McCarthy, Thomas. 1978. The Critical Theory of Jurgen Habermas. Cambridge, MA: The MIT Press.

Mehta, Pratap Bhanu. 2001. "The Ethical Irrationality of the World: Weber and Hindu Ethics." Critical Horizons 2(2): 203-225.

Minton, Arthur J. and Thomas Shipka. 1982. Philosophy: Paradox and Discovery, $2^{\text {nd }}$ Edition. New York, NY: McGraw-Hill Book Company.

Nafissi, Mohammad R. 2000. "On the Foundations of Athenian Democracy: Marx's Paradox and Weber's Solution." Max Weber Studies 1: 56-83.

Pegis, Anton C. 1948. Introduction to St. Thomas Aquinas. New York, NY: Random House.

Rader, Melvin. 1979. Marx's Interpretation of History. New York, NY: Oxford University Press.

Richmond-Wilner, Patricia M. 1982. "The Red Inkwell: Marxists on Literature and Imperialism.” Contemporary Sociology 11(6): 639-642.

Robinson, Joan. 1966. An Essay on Marxian Economics, $2^{\text {nd }}$ Edition. London, England: The MacMillan Press.

Robinson, Robert V. and Jonathan Kelly. 1979. "Class as Conceived by Marx and Dahrendorf: Effects on Income Inequality and Politics in the United States and Great Britain." American Sociological Review 44(1): 38-58.

Ruccio, David F. 2011. "A Review of "Envisioning Real Utopias"” by Eric Olin Wright, London: Verso, 2010.” Historical Materialism 19(4): 219-227.

Swedberg, Richard. 2002. "The Economic Sociology of Capitalism: Weber and Schumpeter." 


\section{Macrothink}

Journal of Sociological Research

ISSN 1948-5468 2012, Vol. 3, No.2

Journal of Classical Sociology 2(3): 227-255.

Sweezy, Paul M. 1981. Four Lectures on Marxism. New York, NY: Monthly Review Press.

Sweezy, Paul M. 1942. The Theory of Capitalist Development (Principles of Marxist Political Economy). New York, NY: Modern Reader Paperbacks.

Tribe, David. 1967. 100 Years of Free Thought. London, England: Elek Books Limited.

Tucker, Robert C. 1961. Philosophy and Myth in Karl Marx. New York, NY: Cambridge University Press.

Tucker, Robert C. (Ed.) 1972. The Marx-Engels Reader. New York, NY: W.W. Norton and Company.

Turner, Stephen P. 1983. "Weber on Action.” American Sociological Review. 48(4): 506-519.

Weber, Max. 1958. The Protestant Ethic and the Spirit of Capitalism. New York, NY: Charles Scribner's Sons.

Weber, Max. [1915] 1964. The Religion of China. (Trans. by H.H. Gerth). New York, NY: The Free Press.

Weber, Max. 1964. The Theory of Social and Economic Organization. New York, NY: The Free Press.

Whimster, Sam. 2005. R.H. Tawney, Ernst Troelsch and Max Weber on Puritanism and Capitalism. Max Weber Studies 5(2): 297-316.

Wright, Erik O. 2010. Envisioning Real Utopias. London, England: Verso. 